\title{
マイクロ電極を用いる有機電解液と金属の安定性の評価
}

\author{
王 献明a, 仁科 辰夫*b, 内田 令 ${ }^{\mathrm{c}}$
}

\section{Evaluation of the Stability of Organic Solutions and Metals by Using Microelectrode Technique}

\author{
Xianming WANG ${ }^{a}$, Tatsuo NISHINA, ${ }^{* b}$ and Isamu UCHIDA ${ }^{c}$ \\ 東北大学大学院工学研究科（广980-8579 仙台市青葉区荒巻字青葉 07) \\ Graduate School of Engineering, Tohoku University(Aramaki-Aoba 07, Aoba-ku, Sendai 980-8579, Japan) \\ a現在：三菱化学㛦)筑波研究所 (示300-0397 茨城県稲敷郡阿見町中央 8-3-1) \\ Present address: Tukuba Research Center, Mitsubishi Chemical Corporation (Chuo 8-3-1, Ami, Inashiki, Ibaraki \\ 300-0397, Japan) \\ b現在：山形大学工学部物質工学科（广992-8510 山形県米沢市城南 4 丁目 3-16) \\ Present address: Department of Materials Science and Engineering, Yamagata University (Jonan 4-3-16, \\ Yonezawa, Yamagata 992-8510, Japan) \\ c現在：東北大学未来科学技術共同研究センター（テ980-8579 仙台市青葉区荒卷字青葉 07） \\ Present address: New Industry Creation Hatchery Center, Tohoku University (Aramaki-Aoba 07, Aoba-ku, \\ Sendai 980-8579, Japan)
}

Received July 2, 1998 ; Accepted October 26, 1998

\begin{abstract}
Microelectrode technique was used to examine the stability of organic solutions and metals because of minimum $i R$ effect on polarization behavior. By diluting the solution, we studied the electrochemical behavior of the solvent and solute separately ; $\mathrm{PC}, \mathrm{PC}+\mathrm{EC}$ solvents and $\mathrm{LiClO}_{4}$ solute were found to be oxidized at $+5.73 \mathrm{~V}$, $+5.77 \mathrm{~V}$ and $+4.40 \mathrm{~V}$, respectively. The cathodic decomposition of $\mathrm{PC}$ and $\mathrm{PC}+\mathrm{EC}$ solvents occurred at negative potentials of $0 \mathrm{~V}$ because of the freshly deposited lithium. The stability of various metals $(\mathrm{Cu}, \mathrm{Mo}, \mathrm{Ni}$, $\mathrm{Pd}$, SUS304, Al, Au, Pt and W) were examined in $1 \mathrm{M}\left(\mathrm{M}=\mathrm{mol} / \mathrm{dm}^{3}\right) \mathrm{LiClO}_{4} / \mathrm{PC}$ solution and categorized according to their anodic and cathodic behaviors.
\end{abstract}

Key Words : Microelectrode, Organic Solution, Metal, Stability

\section{1 緒 言}

電解質に有機電解液，負極に金属りチウムを用いるリチウ 厶二次電池は，負極の充放電効率が低く，充放電寿命が短い という問題点がある ${ }^{1}$. その原因として, 析出したリチウム金 属は, 溶媒や水等の不純物との反応性が極めて高いため, 負 極表面に電気伝導率の低い皮膜が生成することが考えられ $る^{2-3)}$.また，このような有機電解液はイオン伝導率が低く， 電位葖が水溶液系電解液に比較すれば高いもののまだ不充分 であるという物性上の課題も持っている，長寿命・高エネル ギー密度の電池の実用化に当たっては，イオン伝導率が高く， 電位塋が広く，かつリチウムデンドライト析出の抑止効果が 高い有機電解液が求められている。これらの問題を根本から 解決していくためには, まず有機電解液の性質の把握が不可 欠である。

従来のマクロな電極系を用いた有機電解液の電気化学的安 定性に関する研究は, 有機電解液が高抵抗であるため, $i R$ 降 下などの影響が無視できない4-7．また，このような研究は, 有機電解液のイオン伝導率を高めるために, $1 \mathrm{M}(\mathrm{M}=\mathrm{mol} /$ $\left.\mathrm{dm}^{3}\right)$ 程度の高電解質濃度の溶液を用いており, 溶媒のみの
安定性を正確に把握することは困難である。この問題を解決 する対策として，マイク口電極は極めて有效である ${ }^{8}$.すなわ ち， $i R$ 効果を抑止することや溶質濃度を希薄化することに より，溶媒と電解質のレドックス挙動を分離することができ る.

化学電池の実用化の一つの条件としては, 密閉度が高いこ とが挙げられる，そのためには，電解液中における電池の構 造部品（電極集電板，セパレータなど）の電気化学的，化学 的安定性が重要である。カソードに $\mathrm{Li}_{1-x} \mathrm{CoO}_{2} や \mathrm{Li}_{1-x} \mathrm{Mn}_{2}{ }^{-}$ $\mathrm{O}_{4}$ などの活物質を用いる $4 \mathrm{~V}$ 級リチウム二次電池は高い作 動電圧が得られるメリットがある．しかし，その性質のため に, 電池の構造部品の酸化分解が問題となってくる. 特に, 有機電解液之接触する電極集電板材料としての金属の安定性 が要求されている. 従来, 金属の電気化学的安定性に関する 研究は主として水溶液中で行われてきた。非水媒体中での金 属のレドックス挙動に関する研究は幾つか報告されている が9-10), リチウム二次電池の構造部品としての金属材料のア ノ一ド溶解，リチウムとの合金化，及びそれぞれのメカニズ ムなど，いまだに不明な点が多く，電気化学的に安定な金属 
材料開発の明確な指針は現在のところ, 正確には理解されて いないのが現状である。

以上の観点から, 本研究では, リチウム二次電池の長寿命 化を目指した基礎を築くことを目的とし，マイクロ電極を用 い, $1 \mathrm{M} \mathrm{LiClO}_{4} / \mathrm{PC}$ と $\mathrm{PC}+\mathrm{EC}$ 溶液及びその中の各種金 属の安定性を系統的に検討した.

\section{2 実 験}

測定中における水分の混入を防ぐため, 電極挿入口を持つ 真空セルコンテナー内にガラス製セルをセットし，これを真 空ラインに直結した11). セルコンテナー上部のセルキャップ には，各電極類や溶液アンプル等をセットするための SPC$14 \mathrm{~A}$ ポートが数個設けられており, Oリングにより真空タイ トなものになっている。このようなセル構成とすることによ ク，電極の交換を容易に行うことができる. セルコンテナー 内は常に乾燥アルゴンガス雲囲気に保った. アルゴンと二酸 化炭素はガス精製装置（Japan Pionics）により脱水・脱酸 素してセルコンテナー内に導入される．排気側は水銀マノメ 一タを利用したチェックバルブにより外界との遮断を四って いる.

電解液には $1 \mathrm{M} \mathrm{LiClO}_{4} / \mathrm{PC} と \mathrm{PC}+\mathrm{EC}(1: 1)$ 有機電 解液 (三菱化学) とそれらの希釈溶液を用いた。測定中での 溶液の含水量はKarl-Fischer 法 (三菱化成, CA-06 型) に よりチェックしており，20 ppm 以下であることを確認して いる.

電解液とリチウム参照電極は, 予めグローブボックス内で ブレイカブルシール付のガラスアンプル内に封入・作製して あり，使用時にセル内に導入し，シール部を割って使用した。 これは外気, 特に湿気からほほ完全に遮断して保存し, 以後 の実験を簡略化するためである，参照極室は予め真空となっ ており，シール部を割ることにより测定室内の電解液が参照 極室内に導入される。従って, 希釈電解液の場合では $\mathrm{Li}^{+} の$ 濃度も異なるため, 参照極電位が変化してしまうが,これを $\mathrm{Li}^{+}+\mathrm{e} \rightarrow \mathrm{Li}$ なる反応の Nernst 式により $\mathrm{Li}^{+}$の活量として $\mathrm{Li}^{+}$濃度を用いて $\mathrm{Li}^{+}(1 \mathrm{M}) / \mathrm{Li}$ の電位に換算し，標記して いる.

対極にはPtコイルを用い，三極式セルを用いて測定を行 った. すなおち，作用電極と対極は同一測定室に設置されて 抢り, 個々の電極室への分離は行っていない. 作用電極とし ての Pt, W, Moのマイクロディスク電極は, パイレックス ガラス管中に各々半径 $5 \sim 25 \mu \mathrm{m}$ の細線を封入し, ガラス断 面を研磨して作成した. また, マイク口電極の半径は, $0.2 \mathrm{M}$ $\mathrm{Na}_{2} \mathrm{SO}_{4}$ 水溶液中における $5 \mathrm{mM} \mathrm{Fe}(\mathrm{CN})_{6}{ }^{3-}$ 還元反応の $\mathrm{CV}$ 測定を行い，その定常限界電流密度から[1]式を用いて 求めた。

$$
i_{\mathrm{L}}=4 n F C D /(a \pi)
$$

ここで, $i_{\mathrm{L}}$ は定常限界電流密度, $n$ は反応電子数, $F$ はフ アラデー定数, $C$ は $\mathrm{Fe}(\mathrm{CN})_{6}{ }^{3-}$ の濃度, $D$ は $\mathrm{Fe}(\mathrm{CN})_{6}{ }^{3-}$ の 拡散係数, $a$ は電極の半径である. $\mathrm{Al}, \mathrm{Cu}, \mathrm{SUS304,} \mathrm{Pd}$, $\mathrm{Au}, \mathrm{Ni}$ 等の金属は熱膨張係数がパイレクスガラスと大きく 異なるため, それらのマイクロディスク電極はガラス管の先
に接着剤(アラルダイト)で半径 10〜25 $\mu \mathrm{m}$ の金属細線を封 入して作製した。

電気化学測定はPotentiostat/Galvanostat HA-150 (Hokuto Denko), X-Y Recorder WX1000 (Graphtec), Function Generator HB-104 (Hokuto Denko) を用い, アルミ・シールドボックス中で行った.

\section{1 有機電解液の安定性}

\section{3 結果と考察}

これまで, 有機溶媒の酸化電位 $E_{0 x}$ を求めた報文 ${ }^{4-5)}$ は, 高 濃度の支持電解質を含む電解液中において, ある一定電流密 度が流れる電位を酸化電位と定義している場合が多く, 酸化 電位の決定にかなりの任意性が含まれている．電流密度の基 準が違うため $\left(0.1 \sim 1 \mathrm{~mA} / \mathrm{cm}^{2}\right)$, 酸化電位にばらつきがあ る(例之ば PC 系では 4.7 5.3 V). また, この酸化電位が電 解質の分解によるものなのか, 溶媒の分解によるものなのか もはっきりしていない. 本研究ではこの点について, 電解質 濃度を希薄化（～mM）することにより溶質と溶媒の挙動を 分離し, その挙動の解析から妥当な酸化電位を決定すること を試みた。

Fig. 1 に室温での $1 \mathrm{M} \mathrm{LiClO}_{4} / \mathrm{PC}$ 溶液中における $\mathrm{Pt}$ マイクロ電極の CV を示文。掃引開始電位を開路電位の +3.0 $\mathrm{V}$ に設定し, $50 \mathrm{mV} / \mathrm{s}$ の掃引速度でカソード方向へ掃引し た. +1.7 V 付近に一つのカソードピークが観察された。これ は溶液の含水量の増加とともに堌大寸るため, 不純物水の還

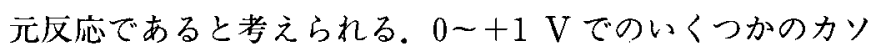
ードピークは Li-Pt 合金の生成によるものであろう ${ }^{12)}$. $0 \mathrm{~V}$ より单な電位でカソード電流が急激に増大するのは，リチウ ムの析出反応によるものである。

電位折り返し後では，0〜+1 V に生成したリチウムとリ チウム合金の酸化に起因する電流が観察された. $+2 \mathrm{~V}$ 付近 のアノードピークは+1.7 Vのカソードピークに対応し, 水 の還元生成物の酸化によるものである。その後アノード電流

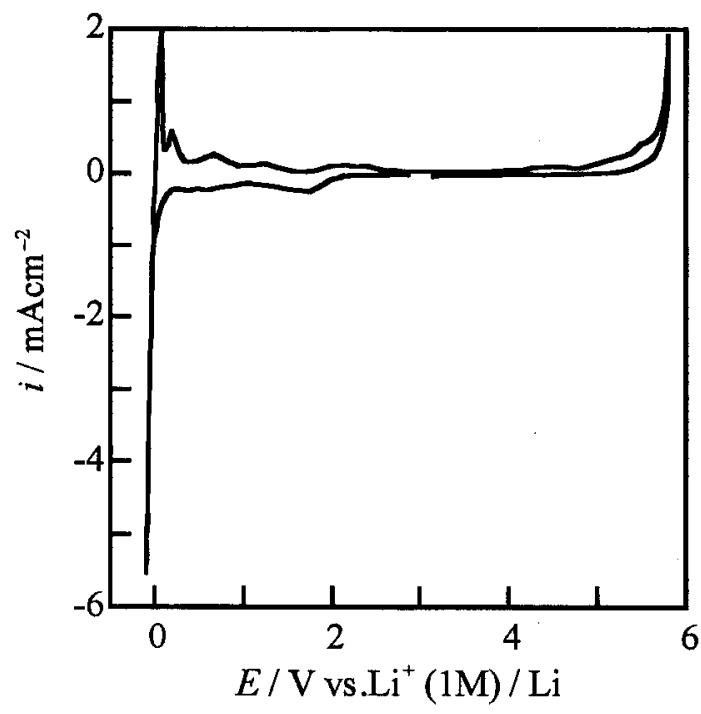

Fig. 1 Cyclic voltammogram at $\mathrm{Pt}$ microdisk electrode (30 $\mu \mathrm{m}$ in dia.) in $1 \mathrm{M} \mathrm{LiClO}_{4} / \mathrm{PC}$ solution at $50 \mathrm{mV} / \mathrm{s}$. 
はほとんど見られなかった。また, $+4 \mathrm{~V}$ 付近からわずかな 酸化電流が流れはじめ, さらに, $+5.7 \mathrm{~V}$ 付近で電流值が急激 に増加した.Ptの電気化学的安定性を考虑すれば,このア， 一ド限界は電解質又は溶媒の酸化分解に起因すると考えられ る.

このような現象を理解するために，以下，アノード限界， カソード限界に分けて，詳細に考察した。

3. 1. 1 アノード挙動 Fig. 2(a) に溶質である $\mathrm{LiClO}_{4}$ の濃度をパラメータとした PC 溶液中における Ptマイクロ 電極の $\mathrm{CV}$ を示す，掃引開始電位は開路電位の+3.0 V であ り，始めにカソード方向に掃引し, $-0.8 \mathrm{~V} て ゙$ 電位を折り返 し，アノード電流が立ち上がった後，開始電位に戻した。一 旦カソード限界まで電位を掃引しているので，その影響がア ノード限界に及ぶ可能性が心配されたが, 開路電位からア， 一ド側に掃引した場合との違いがみられなかったため, カソ 一ド側への掃引の影響は無視できるものと考えている。

$+5.73 \mathrm{~V}$ 付近では電流が急激に立ち上がるが, これは電解 質濃度に依存しないばかりか, 電解質濃度が微少な $3 \mathrm{mM}$ の場合でも $\mathrm{Li}^{+}$の拡散限界電流 (後述の Fig. 5 参照) を遥か にしのぐ大きな電流が流れており, 気泡の発生も見られるこ となどから, Ptの酸化溶解ではなく, PC 溶媒自体の酸化分
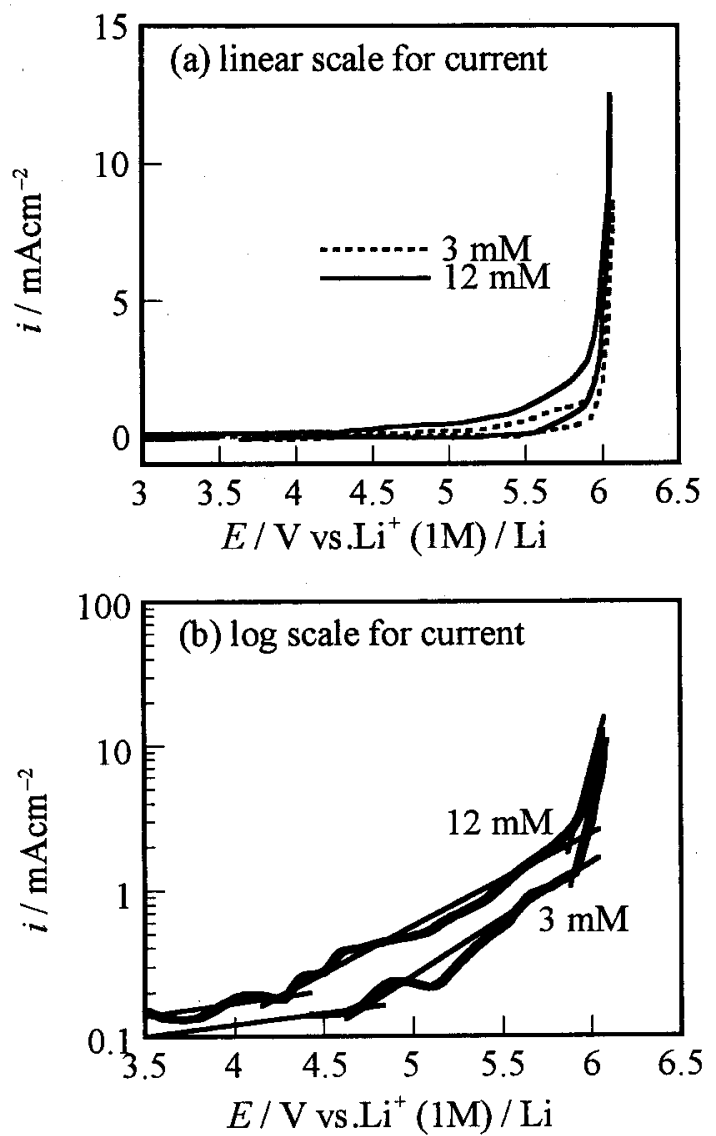

Fig. 2 Cyclic voltammograms at Pt microdisk electrode (15 $\mu \mathrm{m}$ in dia.) in PC solutions containing different concentrations of $\mathrm{LiClO}_{4}$ at $50 \mathrm{mV} / \mathrm{s}$. a ; current was in linear scale, (b) ; current was in log scale like as Tafel plot.
解に起因すると考えられる。

この PC 溶媒自体の酸化分解であるアノード限界の手前に おいて $+4 \mathrm{~V}$ 付近から徐々にアノード電流が增加する領域 が観測された，現在まで報告されている $\mathrm{PC}$ 溶媒の酸化電位 はほほここの電位領域に相当する4-5).この電位領域の電流值は $3 \mathrm{mM}$ から $12 \mathrm{mM}$ と電解質濃度を增加するとともに増大 するように見えるが, $1 \mathrm{M}$ の電解質濃度の場合とほとんど違 いがないばかりか, 逆に $1 \mathrm{M}$ のほうが $12 \mathrm{mM}$ の場合より も流れる電流が小さいという結果が得られている（Fig. 1 参 照)。また, 前述したように $\mathrm{PC}$ 溶媒自体の酸化分解は+5.73 $\mathrm{V}$ よりも貴な領域で起こると考えられるので, 電解質である $\mathrm{ClO}_{4}{ }^{-}$の酸化に対応していると考えられる. しかし, その電 流值の絶対值は, カソード限界で見られる $\mathrm{Li}^{+}$の拡散限界電 流（後述の Fig. 5 参照）よりも遙かに小さく，搪散支配電流 とは考之難いため, 電荷移動過程律速あるいは活性化支配と 考えられる。

Mann 等13) は過塩素酸アニオンに関して, 式(1), (2)に示す ラジカル酸化反応を提案している。

$$
\begin{aligned}
& \mathrm{ClO}_{4}{ }^{-} \rightarrow \mathrm{ClO}_{4}+\mathrm{e} \\
& \mathrm{ClO}_{4} \rightarrow \mathrm{ClO}_{2}+2 \mathrm{O}_{\mathrm{ad}}
\end{aligned}
$$

Eggert 等 ${ }^{14)} 1 \mathrm{M} \mathrm{LiClO}_{4} / \mathrm{PC}$ 溶液中でのこのアノー ド電流に注目し $(+1.6 \mathrm{~V}$ vs. NHE, ca. $+4.60 \mathrm{~V}$ vs. Li $)$, mass spectroscopyにより生成した $\mathrm{ClO}_{2}$ を確認している。 従って,この+4 V 付近の酸化電流は $\mathrm{ClO}_{4}{ }^{-}$イオンの酸化反 応であると考えるのが妥当であろう。あるいは， $\mathrm{Pt}^{2+}$ 生成の 熱力学的な電位が $\mathrm{Li}^{+} / \mathrm{Li}$ 基準において $4.23 \mathrm{~V}$ であること を考虑すれば，(3)式の反応によってできた酸素の吸着あるい は Pt 酸化皮膜の生成も起こっている可能性も否定できない が，その反応速度は非常に遅いものであろう。

$+4 \mathrm{~V}$ 付近の $\mathrm{ClO}_{4}^{-}$イオンの酸化領域と $\mathrm{PC}$ 溶媒分解領 域の電流は，いずれも拡散支配ではなく，活性化支配と考え られる。そこで CV 波形のアノード掃引部分を取り出し, 電 流軸を対数でプロット（ターフェル型のプロット）したとこ ろ, Fig. 2(b) が得られた. ターフェル型のプロットにおいて は低電流領域はそのノイズが拡大されてしまうという久点が みられるが, $\mathrm{ClO}_{4}^{-}$イオンの酸化領域と $\mathrm{PC}$ 溶媒分解領域と では勾配の異なるふたつの直線領域が存在することは明白で あろう. 従って, この直線領域の外挿線の交点から $\mathrm{ClO}_{4}{ }^{-}$イ オンの酸化分解電位や PC 溶媒の酸化分解電位を決定するの は妥当な手法であると考えられる。このようにして $3 \mathrm{mM}$, $12 \mathrm{mM}$ のそれぞれに対して求めた $\mathrm{ClO}_{4}^{-}$イオンの酸化分 解電位は $4.72 \mathrm{~V}$ と $4.26 \mathrm{~V}, \mathrm{PC}$ 溶媒の酸化分解電位は 5.90 $\mathrm{V}$ と $5.89 \mathrm{~V}$ であった。

以上の結果をもとに, $1 \mathrm{M} \mathrm{LiClO}_{4} / \mathrm{PC}$ 及び $\mathrm{PC}+\mathrm{EC}$ 系 の溶媒の酸化分解電位の決定を温度をパラメータとして試み た.その結果を Fig. 3(a) 及び (b) に示す.アノード電流が急 激に立ち上がる溶媒の酸化分解電位は温度の増加とともに告 になり，アノード分解電流も大きくなった。これは温度の増 加とともに溶媒の酸化分解が起こりやすくなることを示唆し ている. 

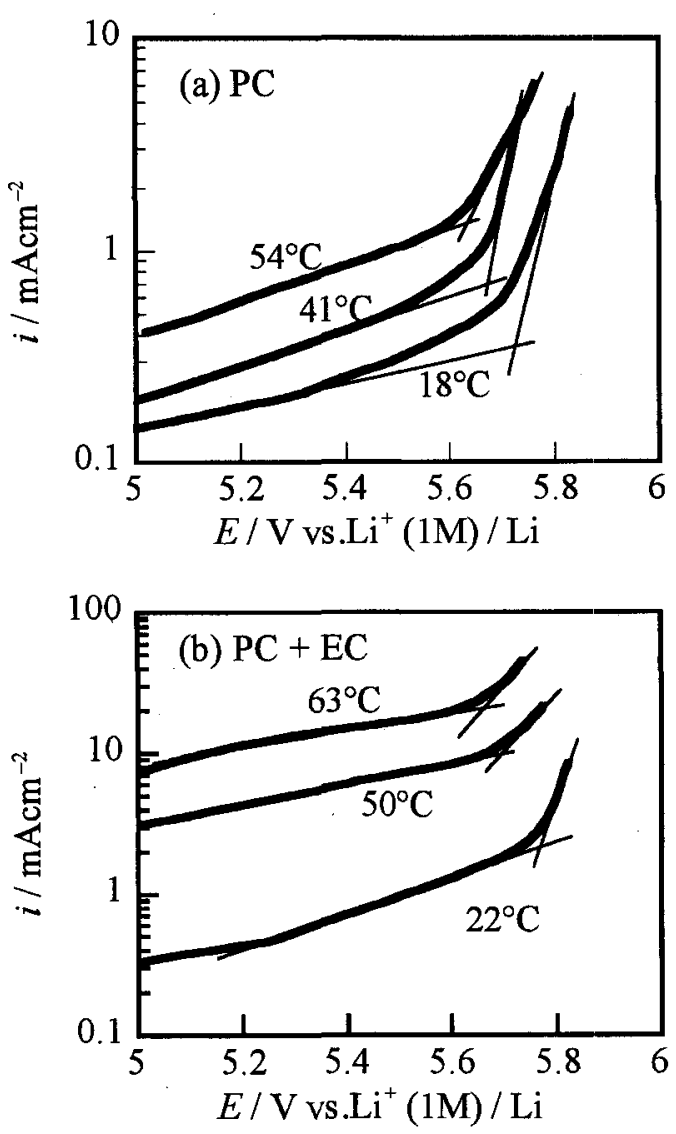

Fig. 3 The effect of temperature on cyclic voltammograms at Pt microdisk electrode $(30 \mu \mathrm{m}$ in dia.) in (a) $1 \mathrm{M}$ $\mathrm{LiClO}_{4} / \mathrm{PC}$ and (b) $1 \mathrm{M} \mathrm{LiClO}_{4} / \mathrm{PC}+\mathrm{EC}$ solutions at 50 $\mathrm{mV} / \mathrm{s}$.

Fig. 4 にはFig. 3 から得られた各溶媒の酸化分解電位の 温度依存性をアレニウス型類似のプロットとして示した。本 研究における測定温度範囲では良好な直線関係が得られ, 酸 化分解電位 $E_{0 x}$ と絶対温度 $T$ との関係は以下の実験式に従 うことが分かった。

$$
\begin{array}{ll}
E_{0 x}=4.93+\frac{231}{T} & \text { for PC } \\
E_{0 x}=4.92+\frac{250}{T} & \text { for PC }+\mathrm{EC}
\end{array}
$$

すなわち，その差はごくわずかであり，酸化電位という観点 からは PC 溶媒より $\mathrm{PC}+\mathrm{EC}$ 溶媒のほうがほんのわずかだ け優れたアノード安定性を有すると言える。(4)式や(5)式の上 うに酸化電位が $1 / T$ に比例するという理諭的な根拠はな いのであるが, 少なくとも室温から $60{ }^{\circ} \mathrm{C}$ 程度の温度領域で は良好な直線関係が得られており，反応機構に扔けるなんら かの速度論的な寄与，あるいは熱力学的な $\Delta \mathrm{G} の$ 変化がある ものと予想され，興味媣い. Table 1 にこれらの結果をまと めて示す。

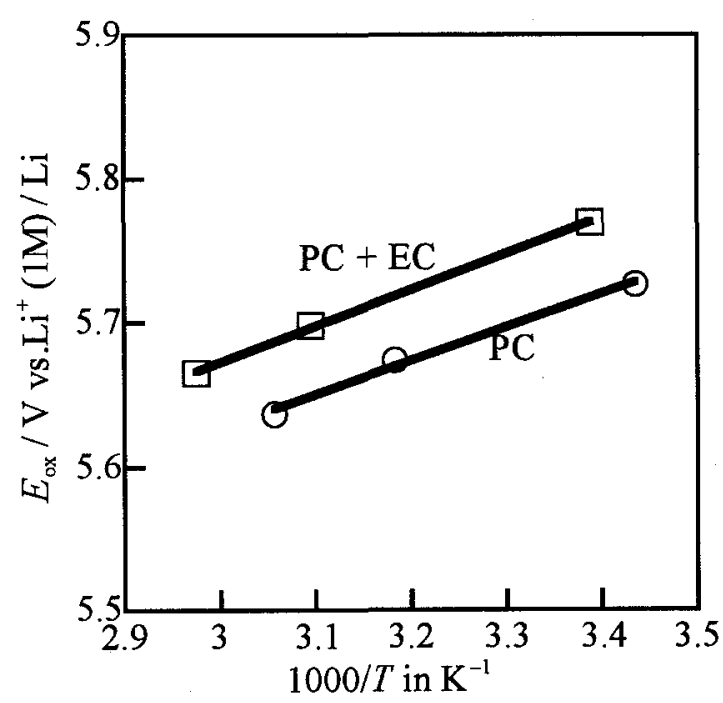

Fig. 4 Effect of temperature on the anodic oxidation potential $E_{0 x}$ of $\mathrm{PC}$ and $\mathrm{PC}+\mathrm{EC}$ solvent obtained from Fig. 3.

Table 1 Anodic oxidation potentials of $\mathrm{PC}$ and $\mathrm{PC}+\mathrm{EC}$

\begin{tabular}{|c|c|c|c|c|c|c|c|}
\hline & & $\mathrm{PC}$ & & & $\mathrm{EC}$ & & $\mathrm{LiClO}_{4}$ \\
\hline$T /{ }^{\circ} \mathrm{C}$ & 18 & 41 & 54 & 22 & 50 & 63 & 18 \\
\hline \multirow{2}{*}{$E_{0 x} / V$ vs. $\operatorname{Li}^{+}(1 \mathrm{M}) / \mathrm{Li}$} & 5.73 & 5.67 & 5.64 & 5.77 & 5.70 & 5.67 & 4.40 \\
\hline & \multicolumn{3}{|c|}{$E_{0 x}=4.93+\frac{231}{T}$} & \multicolumn{4}{|c|}{$E_{0 x}=4.92+\frac{250}{T}$} \\
\hline
\end{tabular}
solvents and $\mathrm{LiClO}_{4}$ electrolyte at different temperatures.

3. 1.2 カソード挙動 Fig. 5 に希薄 $\mathrm{LiClO}_{4}$ 液中での Ptマイクロ電極のカソード限界を示す. $-0.3 \mathrm{~V}$ 付近から還 元電流が徐々に流れはじめるが，これはリチウム析出の核生 成過電圧と平衡電位の濃度依存性に起因する。一度生成した 核表面上でのリチウム析出は容易に進行するため, 電位折り 返し後の電流值の方が大きいという典型的な核生成ループが 見られた。リチウムの析出に続いて，還元電流がややフラッ 卜になった後, 急激に電流が増大した。この還元電流がフラ ットになる領域は $\mathrm{Li}^{+}$の拡散律速によるリチウム析出過程 であり，その詳細については別報にて報告している ${ }^{15}$ ，また， この還元電流が急激に增大寸る電位は, 電解質濃度が $3 \mathrm{mM}$ から $12 \mathrm{mM}$ まで増加するとともに若干貴にシフトしてい るが, その差は小さい，従って，この急激な電流增加は電解 質である $\mathrm{ClO}_{4}-$-の分解ではなく, 溶媒である $\mathrm{PC}$ の分解と 考えられる， $\mathrm{PC}+\mathrm{EC}$ 系の場合も同様に，リチウム析出電流 に続き，溶媒の分解電流か観察された。この溶媒分解挙動に 関してはPC系の場合との差はほとんど見られていない。 Aurbach 等 ${ }^{16)}$ は既に in situ FTIRにより式(6)，(7)に示す 金属リチウムと $\mathrm{PC}$ 及び $\mathrm{EC}$ 溶媒との電気化学的な反応を確 認している。

$$
\begin{array}{r}
2 \mathrm{PC}+2 \mathrm{Li}^{0}+2 \mathrm{e} \rightarrow \mathrm{CH}_{3} \mathrm{CH}\left(\mathrm{OCO}_{2} \mathrm{Li}\right) \mathrm{CH}_{2} \mathrm{OCO}_{2} \mathrm{Li} \downarrow \\
+\mathrm{CH}_{3} \mathrm{CH}=\mathrm{CH}_{2} \uparrow(6
\end{array}
$$




$$
2 \mathrm{EC}+2 \mathrm{Li}^{0}+2 \mathrm{e} \rightarrow\left(\mathrm{CH}_{2} \mathrm{OCO}_{2} \mathrm{Li}\right)_{2} \downarrow+\mathrm{CH}_{2}=\mathrm{CH}_{2} \uparrow
$$

従って,この還元電流は析出したリチウム上で猚行する $\mathrm{PC}$ 又は EC 溶媒の分解に起因すると考えられる，PC系の場合 にはPCの分解であるということができるが, $\mathrm{PC}+\mathrm{EC}$ 系の 場合は PC と EC どちらが分解しやすいのかを確かめること はできなかった。ここで言えるのは PC 系も $\mathrm{PC}+\mathrm{EC}$ 系も ほとんぞ同じであるということである。いずれにしても，析 出した $\mathrm{Li}$ 金属上での分解反応になるので， $\mathrm{Li}$ 金属表面上に 生成する固体電解質 (SEI) 層等の影響も受けやすく, 実験技 術上の困難を伴うと考えられるため, 今後の研究展開に期待 したい.

\section{2 金属の安定性}

3. 2. 1 アノード挙動 ここでは, $1 \mathrm{M} \mathrm{LiClO}_{4} / \mathrm{PC}$ 溶液中での各種金属の CV 測定において，アノード電流が立 ち上がるところの電位を系統的に整理し，耐酸化性の強い金 属材料を探索した. CV 测定は開路電位に掃引開始電位を設 定し、アノード方向に $50 \mathrm{mV} / \mathrm{s}$ の掃引速度で掃引し、アノー ド電流が立ち上がる電位を金属のアノード限界とする。

Fig. 6 は Cu, Ni, Mo, SUS304, Pd, Al, W のアノー ド側の CVである.Cuの場合,アノード電流の立ち上がりは 電解液の酸化分解電位 $(+5.7 \mathrm{~V})$ 上り卑な電位 $(+3.5 \mathrm{~V})$ で起こったため，金属の酸化溶解に起因すると考えられる. また, SUS304, Mo, Ni，Pdのような金属は同様なアノ一 ド挙動を示し，金属自身が電解液より酸化されやすいことが 判った.

一方, $\mathrm{A} 1$ の場合, $+7.5 \mathrm{~V}$ という貴な電位でも,アノード電 流の立ち上がりが観察されなかった，即ち，金属の酸化溶解 と溶媒の酸化分解は共に起っていない. 水溶液中でも, $\mathrm{Al}$ 金 属は酸化物生成により不㗢態化することがよく知られてい る ${ }^{17}$. 有機溶液中でも同様に, $\mathrm{A} 1$ 金属の優れたアノード安定 性は電極表面の不働態化に起因すると考えられる. $\mathrm{W}$ 金属も

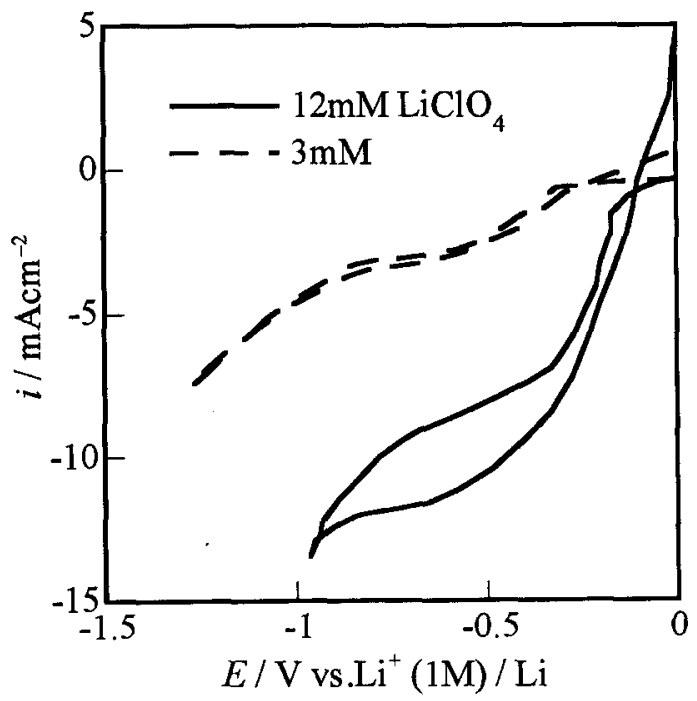

Fig. 5 Cyclic voltammograms at Pt microdisk electrode $\left(15 \mu \mathrm{m}\right.$ in dia.) in $3 \mathrm{mM}$ and $12 \mathrm{mM} \mathrm{LiClO}_{4} / \mathrm{PC}$ solutions at $50 \mathrm{mV} / \mathrm{s}$.

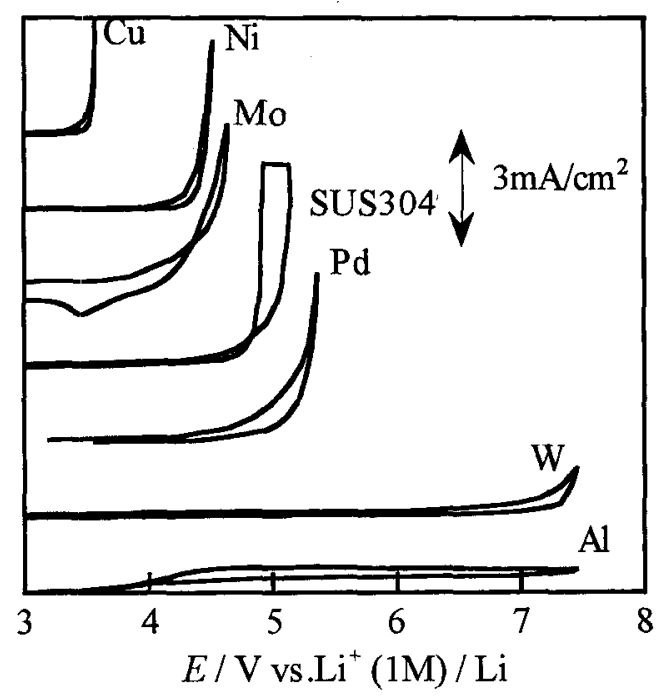

Fig. 6 Anodic limits of $\mathrm{Cu}(50 \mu \mathrm{m}$ in dia.), $\mathrm{Ni}(25 \mu \mathrm{m}$ in dia.), Mo (50 $\mu \mathrm{m}$ in dia.), SUS304 (20 $\mu \mathrm{m}$ in dia.), Pd (30 $\mu \mathrm{m}$ in dia.), Al (25 $\mu \mathrm{m}$ in dia.), and $\mathrm{W}(10 \mu \mathrm{m}$ in dia.) microdisk electrodes in $1 \mathrm{M} \mathrm{LiClO}_{4} / \mathrm{PC}$ solution obtained by cyclic voltammograms at $50 \mathrm{mV} / \mathrm{s}$.

優れたアノード安定性を示す．現在のところ，実用化されて いるリチウム二次電池がカソード (正極) 集電板材料に $\mathrm{A} 1$ を 用いているのは，不働態化による耐食性ならびに溶媒分解の 不活性さの観点からは妥当である17). Table 2 に $1 \mathrm{M}$ $\mathrm{LiClO}_{4} / \mathrm{PC}$ 溶液中での各種金属のアノード限界をまとめ て示す.

3. 2.2 カソード挙動習兵電池のアノード (負極)集電板に用いられる金属材料は極好て哚いカソード分 極 (通常 $0 \sim+1 \mathrm{~V}$ ) 下にあり，ある種の金属はリチウムと合 金化し，体積膨張などにより機械的に電池構造が破壊された りすることも有り得る。従って，リチウム二次電池の安定性 向上には, $0 \sim+1 \mathrm{~V}$ の電位範囲で電気化学的に安定な金属 材料の評洒が不可欠である。このような観点から，本節では， $1 \mathrm{mV} / \mathrm{s}$ の掃引速度で測定した CV を用い, 金属のカソード 挙動を考察した。 0 +1 V の電位範囲にカソード電流波が 観察されるかどうかをリチウムの合金化の判断基準とする.

Fig. 7 には $\mathrm{Au}, \mathrm{Al}, \mathrm{Pt}, \mathrm{Pd}, \mathrm{Cu}, \mathrm{Mo}, \mathrm{Ni}, \mathrm{SUS} 304$,

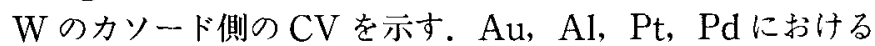
共通点は, $0 \sim+1 \mathrm{~V}$ の電位範囲において明瞭なカソード電 流波が観察されたという点である，前述したように，電解質 や溶媒の還元分解は $-1 \mathrm{~V}$ 付近の非常に卑な電位で, また水 のような不純物の還元反応は $+1 \mathrm{~V} よ り$ 貴な電位で起こる

Table 2 Anodic limiting potentials of various metals in $1 \mathrm{M} \mathrm{LiClO}_{4} / \mathrm{PC}$ solution.

\begin{tabular}{|c|c|c|c|c|c|c|c|}
\hline Metal & $\mathrm{Pt}$ & $\mathrm{Cu}$ & $\mathrm{Ni}$ & SUS304 & $\mathrm{Pd}$ & $\mathrm{Mc}$ & $\overline{\mathrm{W}} \quad \overline{\mathrm{Al}}$ \\
\hline$E_{2 x} / V$ us $\mathrm{Lit}^{+}(\mathrm{M}) / \mathrm{Li}$ & 5.7 & 3.5 & 4.4 & 5.0 & 4.8 & 4.5 & $>6.0>6.0$ \\
\hline Note & $\begin{array}{c}\mathrm{PC} \\
\text { Decomposition }\end{array}$ & & & $\begin{array}{l}\text { Metal } \\
\text { issolutic }\end{array}$ & & & Passivation \\
\hline
\end{tabular}




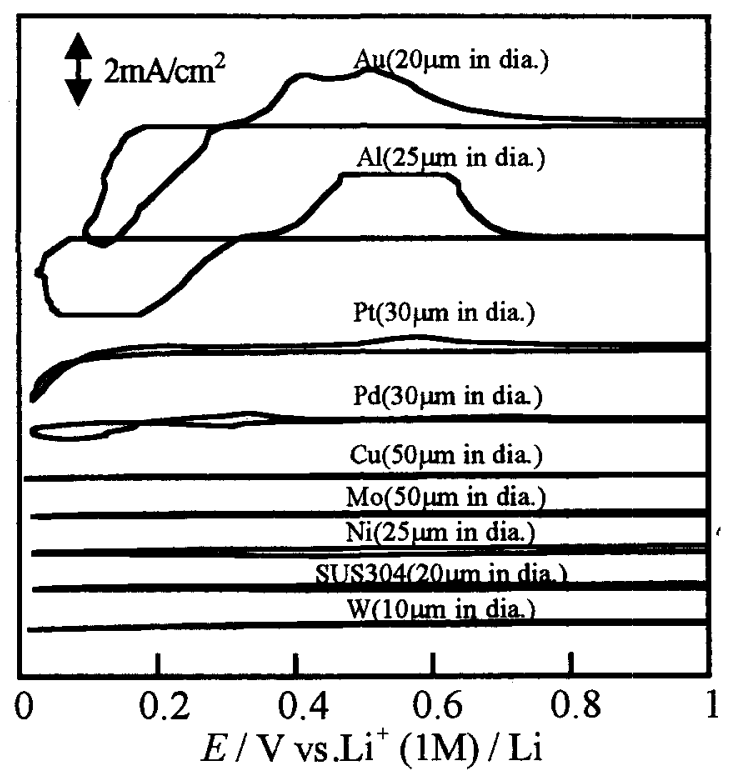

Fig. 7 Cathodic limiting region of cyclic voltammograms at various microdisk electrodes with lithium in $1 \mathrm{M}$ $\mathrm{LiClO}_{4} / \mathrm{PC}$ solution at $1 \mathrm{mV} / \mathrm{s}$.

ため,このカソード電流は金属とリチウムとの合金化に起因 すると判断される。これらの金属は合金化に伴う体積膨張の ため,リチウム二次電池のアノード (負極) 集電板としては 使用できない。

一方, $\mathrm{Cu}, \mathrm{Mo}, \mathrm{Ni}, \mathrm{SUS304, \textrm {W }}$ の場合, $0 \sim+1 \mathrm{~V}$ の 電位範囲には明瞭なカソード電流波が観察されなかった。従 ってこのような金属はリチウムと合金化しないと判断でき， リチウム二次電池用アノード集電板として期待できる. 現在 のところ, 実用化されているリチウム二次電池はアノード集 電板材料に $\mathrm{Cu}$ を用いていることは周知のとおりである ${ }^{18)}$.

\section{4 結 論}

本研究では, リチウム二次電池関連の種々の金属材料及び 有機溶液の安定性について検討し，以下の知見を得た。

1. 溶質濃度の希薄化により, 有機溶液の $\mathrm{LiClO}_{4} / \mathrm{PC}$ 中で の溶質と溶媒のレドックス挙動の分離を試み，その電位

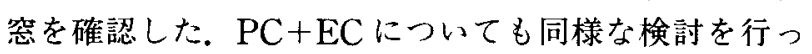
た.

のアノード限界：溶質 $\mathrm{LiClO}_{4}$ の酸化反応は $+4.40 \mathrm{~V}$ 付近に起こった，室温で PC と PC+EC 溶媒の酸化 分解電位はそれぞれ+5.73 V と+5.77 Vであった。

○カソード限界：0 Vより杽な電位で起こる析出した
リチウムと PC 及び PC+EC 溶媒の分解を確認した。 -PC $+\mathrm{EC}$ 溶媒の挙動は，PC 溶媒と酷似しており，ほ とんど違いが見られなかっった。

2. 種々の金属のアノード限界の決定とリチウムとの合金化 の検討を行った.

- $\mathrm{Cu}, \mathrm{Mo}, \mathrm{Ni}, \mathrm{Pd}, \mathrm{SUS} 304$ 等の金属は PC 溶液中 で酸化溶解する. Al, W 等の金属は PC 溶液中で電極 表面の不働態化により安定化し，4 V 級リチウム二次 電池用カソード集電板材料として適している.

-Al, Pt, $\mathrm{Pd}, \mathrm{Au}$ 等の金属はりチウムと合金化する. 一方, $\mathrm{Cu}, \mathrm{Mo}, \mathrm{Ni}, \mathrm{SUS} 304, \mathrm{~W}$ 等の金属はりチウ ムと合金化しないことが確認できた。

\section{文 献}

1) K. M. Abraham and S. B. Brummer, Lithium Batteries, (Ed. J-P. Gabano), Academic Press, New York, NY, 371 (1983).

2) E. Peled, J. Electrochem. Soc., 126, 2047 (1979).

3) D. Aurbach, O. Youngman, Y. Gofer, and A. Meitiv, Electrochim. Acta, 35, 625 (1990).

4) S. Tobishima and T. Okada, Electrochim. Acta, 30, 1715 (1985).

5) F. Ossola, G. Pistoia, R. Eeber, and P. Ugo, Electrochim. Acta, 33, 47 (1988).

6) Y. Malik, D. Aurbach, P. Dan, and A. Meitav, J. Electroanal. Chem., 282, 73 (1990).

7) Z. Stoinov, B. Savova-Stoinov, and T. Kossev, J. Power Sources, 30, 275 (1990).

8) M. Fleichmann, S. Pons, D. R. Rolison, and P. P. Schmidt, Ultramicroelectrodes, Datatech Systems Inc., Morganton, NC (1987).

9) R. G. Kelly, P. J. Moran, J. Kruger, C. Zollman, and E. Gileadi, J. Electrochem. Soc., 136, 3262 (1989).

10) J. F. Scanlon, J. Kruger, and P. J. Moran, J. Electrochem. Soc., 140, 1268 (1993).

11) 王 献明, 壬科辰夫, 内田 勇, 表面技術, 46, 941 (1995).

12) R. Jasinki, Adv. Electrochem. Electrochem. Eng., Vol. 8, (Eds. P. Delahay and C. W. Tobias), Interscience, New York, NY (1971).

13) C. Mann and K. Barnes, Electrochemical Reactions in Nonaqueous Systems, Marcel Dekker, New York, NY (1970).

14) G. Eggert and J. Heitbaum, Electrochim. Acta, 31, 1443 (1986).

15) X-M. Wang, T. Nishina, and I. Uchida, J. Power Sources, 68, 483 (1997).

16) D. Aurbach, Y. Ein-Ely, and A. Zaban, J. Electrochem. Soc., 141, L1 (1994).

17）日本金属学会, 金属表面物性工学, 丸善, 171 (1990).

18) S. Megahed and B. Scrosati, Interface, Winter, 34 (1995). 